\title{
Synthesis of novel conjugates of a saccharide, amino acids, nucleobase and the evaluation of their cell compatibility
}

\author{
Dan Yuan ${ }^{1}$, Xuewen Du ${ }^{1}$, Junfeng Shi ${ }^{1}$, Ning Zhou ${ }^{1}$, Abdulgader Ahmed Baoum ${ }^{2}$ \\ and Bing $X u^{* 1}$
}

\author{
Full Research Paper \\ Address: \\ 1Department of Chemistry, Brandeis University, 415 South Street, \\ MS015, Waltham, MA 02453, USA and 2Department of Chemistry, \\ King Abdulaziz University, Jeddah, Saudi Arabia \\ Email: \\ Bing Xu* - bxu@brandeis.edu \\ ${ }^{*}$ Corresponding author \\ Keywords: \\ cell compatibility; nucleobase; peptides; saccharide
}

Beilstein J. Org. Chem. 2014, 10, 2406-2413. doi:10.3762/bjoc. 10.250

Received: 12 June 2014

Accepted: 01 October 2014

Published: 16 October 2014

Associate Editor: K. N. Ganesh

(C) 2014 Yuan et al; licensee Beilstein-Institut. License and terms: see end of document.

\begin{abstract}
This article reports the synthesis of a novel type of conjugate of three fundamental biological build blocks (i.e., saccharide, amino acids, and nucleobase) and their cell compatibility. The facile synthesis starts with the synthesis of nucleobase and saccharide derivatives, then uses solid-phase peptide synthesis (SPPS) to build the peptide segment (Phe-Arg-Gly-Asp or naphthAla-Phe-ArgGly-Asp with fully protected groups), and later, an amidation reaction in liquid phase connects these three parts together. The overall yield of these multiple step synthesis is about $34 \%$. Besides exhibiting excellent solubility, these conjugates of saccharide-amino acids-nucleobase (SAN), like the previously reported conjugates of nucleobase-amino acids-saccharide (NAS) and nucleobase-saccharide-amino acids (NSA), are mammalian cell compatible.
\end{abstract}

\section{Introduction}

As a result of evolution, nature selects saccharides, peptides, and nucleobases as the fundamental building blocks for the creation of biomacromolecules, which lay the molecular foundations of life. This simple fact and the self-assembly of small molecules in water have inspired us to explore the conjugates of those three types of building blocks for generating supramolecular nanofibers in water [1-15]. Recently, we have demonstrated that not only the conjugates of nucleobase-amino acids-saccharide (NAS) [16-18] but also the conjugates of nucleobase-saccharide-amino acids (NSA) [19] are able to selfassemble to form supramolecular hydrogels and exhibit promising biological functions, such as promoting the development of zygotes [20]. Moreover, both NAS- and NSA-type conjugates exhibit excellent cell compatibility. Except for a few known motifs (naphthalene [21,22], Fmoc [23,24], lipid [25]), it is still challenging to judge which molecules could selfassemble to form ordered nanostructures. This challenge requires the molecular engineering of the conjugates and intense 
study of their properties to provide a molecular basis for the understanding of the fundamental correlation between molecular structure and self-assembly.

Here we investigate new molecular conjugates made of basic building blocks by connecting a saccharide segment to amino acids, and nucleobase (i.e., saccharide-amino acids-nucleobase, we term it SAN-type). As shown in Figure 1, in the conjugates 1-4, the saccharide is glucuronic acid, the amino acid segment consists of Phe-Arg-Gly-Asp or naphthAla (3-(2-naphthyl)alanine)-Phe-Arg-Gly-Asp, and the nucleobase is thymine or adenine. Our results show that the conjugates synthesized and examined in this work exhibit excellent cell compatibility but are unable to self-assemble in water to form hydrogels. Their excellent solubility in water implies that these molecules may find applications for breaking up molecular aggregates in water, a much-needed property for warranting genuine monomeric ligand-receptor interactions. The conjugates $\mathbf{5}-\mathbf{8}$, without a saccharide segment, have good solubility at acidic conditions, also present great cell compatibility and dissolve well in water. These results imply that glucuronic acid is unlikely to be the key factor for cell compatibility of SAN-type conjugates.

\section{Results and Discussion Molecular design}

Figure 1 shows the structures of the designed molecules based on the mutation of the sequence of the connection of nucleobase, amino acids, and saccharide. To explore the properties of the conjugates dependent on the relative positions of the building blocks we synthesized conjugates having the following order: saccharide-amino acids-nucleobase (i.e., SAN-type, 1-4). Although oligosaccharide moieties serve as constituents of glycoproteins in a broad range of cell-cell and cell-matrix recognition events, the introduction of glucuronic acid into<smiles>N=C(N)NCCCC(NC(=O)[C@H](Cc1ccccc1)NC(=O)[C@@H]1OC(O)C(O)C(O)C1O)C(=O)NCC(=O)NC(CC(=O)O)C(=O)NCCn1cnc2c(N)ncnc21</smiles><smiles>Cc1cn(CCNC(=O)C(CC(=O)O)NC(=O)CNC(=O)C(CCCNC(=N)N)NC(=O)[C@H](Cc2ccccc2)NC(=O)C2OC(O)C(O)C(O)C2O)c(=O)[nH]c1=O</smiles><smiles>N=C(N)NCCCC(NC(=O)C[C@H](Cc1ccccc1)NC(=O)C(Cc1ccc2ccccc2c1)NC(=O)[C@H]1OC(O)C(O)C(O)C1O)C(=O)NC(=O)NC(CC(=O)O)C(=O)NCCn1cnc2c(N)ncnc21</smiles><smiles>Cc1cn(CCNC(=O)C(CC(=O)O)NC(=O)CNC(=O)C(CCCCNC(=N)N)NC(=O)[C@H](Cc2ccccc2)NC(=O)C(Cc2ccc3ccccc3c2)NC(=O)[C@H]2OC(O)[C@H](O)[C@@H](O)C2O)c(=O)[nH]c1=O</smiles><smiles>N=C(N)NCCCC(NC(=O)[C@H](N)Cc1ccccc1)C(=O)NCC(=O)NC(CC(=O)O)C(=O)NCCn1cnc2c(N)ncnc21</smiles><smiles>Cc1cn(CCNC(=O)C(CC(=O)O)NC(=O)CNC(=O)C(CCCNC(=N)N)NC(=O)[C@H](N)Cc2ccccc2)c(=O)[nH]c1=O</smiles><smiles>[Y]c1cccc(C[C@H](NC(=O)C(N)Cc2ccc3ccccc3c2)C(=O)N[C@@H](CCCNC(=N)N)C(=O)NCC(=O)NC(CC(=O)O)C(=O)NCCn2cnc3c(N)ncnc32)c1</smiles><smiles>Cc1cn(CCNC(=O)C(CC(=O)O)NC(=O)CNC(=O)C(CCCNC(=N)N)NC(=O)[C@H](Cc2ccccc2)NC(=O)C(N)Cc2ccc3ccccc3c2)c(=O)[nH]c1=O</smiles>

Figure 1: Chemical structures of the saccharide-amino acids-nucleobase conjugates (SAN, 1-4) and amino acids-nucleobase (AN, 5-8). 
peptides at the $N$-terminus (Figure 1) is rare and worth the exploration [26]. As an amino acid, Phe or naphthAla increases molecular aromatic-aromatic interactions [19,21,27]. Arg-GlyAsp, which is a well-established tripeptidic epitope, that modulates mammalian cell adhesion through binding with integrins on the cell membrane $[28,29]$. Thymine or adenine, as a unique types of heteroatom aromatics, not only promote self-assembly [30], but also have the capability for DNA delivery [16]. To examine the role of the saccharide, we also designed and synthesized the respective conjugates of amino acids and nucleobase without the glucuronic moiety (5-8) for comparison.

\section{Synthesis}

Schemes 1-4 show the syntheses of the SAN conjugates formed by the reaction of the amino acid segment with the nucleobase and the saccharide derivative. The key steps include $N$-alkylation, acetylation, solid-phase peptide synthesis (SPPS) and $\mathrm{N}$-hydroxysuccinimide (NHS) $/ \mathrm{N}, \mathrm{N}$-diisopropylcarbodiimide (DIC)-catalyzed amidation reaction. As demonstrated by the example of the synthesis of $\mathbf{3}$, the use of reported methods [3135] (Scheme 1) affords the nucleobase and saccharide derivatives 12, 16, and 19. We used SPPS [36] (Scheme 2) to synthesize the fully protected naphthAla-Phe-Arg-Gly-Asp (20). After loading the first amino acid (Fmoc-Asp $(\mathrm{O} t-\mathrm{Bu})-\mathrm{OH})$ on the 2-chlorotrityl chloride resin, we blocked the resin by dichloromethane (DCM)/methanol (MeOH)/N,N-diisopropylethylamine (DIEA) $(8: 1.5: 0.5)$, next removed the Fmoc protecting group by $20 \%$ piperidine in $N, N$-dimethylformamide (DMF), then used the coupling reagent $N, N, N^{\prime}, N$ '-tetramethyl-
$O$-(1H-benzotriazol-1-yl)uronium hexafluorophosphate (HBTU)/DIEA to connect the following $N$-Fmoc amino acid (i.e., Fmoc-Gly-OH, Fmoc-Arg(pbf)-OH, Fmoc-Phe-OH, Fmoc-3-(2-naphthyl)alanine) by repeating the deprotection and coupling steps. At last, we cleaved the pentapeptide $\mathbf{2 0}$ with all protected groups from the resin by using trifluoroethanol (TFE)/ $\operatorname{DCM}(2 / 8,2 \times 1$ hour). The reaction of $\mathbf{2 0}$ and NHS/DIC activates the carboxyl group on $\mathbf{2 0}$ to couple with $\mathbf{1 2}$ at $\mathrm{pH} 8.5$, which results in $\mathbf{2 1}$. The subsequent removal of the Fmoc group provides the protected nucleopeptide 22 [30] (Scheme 3). The activation of $\mathbf{1 9}$ to react with $\mathbf{2 2}$ and the subsequent removal of Fmoc results in 23. Finally, treatment of $\mathbf{2 3}$ with $95 \%$ trifluoroacetic acid (TFA) for 1 hour and triethylamine $\left(\mathrm{Et}_{3} \mathrm{~N}\right) / \mathrm{MeOH} /$ $\mathrm{H}_{2} \mathrm{O}$ 1:4:5) for 2 hours affords conjugate 3 (Scheme 4). By changing the nucleobase and using the similar reaction procedures, we obtained the rest of the conjugates shown in Figure 1.

\section{Inability of hydrogelation}

Unlike the NAS- and NSA-type conjugates, none of the SANtype conjugates form hydrogels at the conditions tested. As shown in Supporting Information File 1, Figure S1A, B, 1 or 2 form a viscous aqueous solution at a concentration of $3 \mathrm{wt} \%$ ( $\mathrm{pH}$ 4.0) after one week aging. Although our previous study shows that the incorporation of naphthAla, a naphthalenecontaining unnatural amino acid, into NSA is able to induce hydrogelation [19], the introduction of naphthAla to $\mathbf{1}$ or $\mathbf{2}$, which makes conjugate $\mathbf{3}$ or $\mathbf{4}$, however, is unable to result in hydrogelation (Supporting Information File 1, Figure S2A and<smiles></smiles><smiles>O=C(O)[C@H]1OC(O)[C@H](O)C(O)[C@H]1O</smiles>

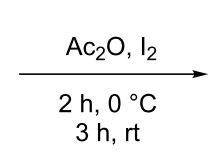<smiles>CC(=O)OC1OC(C(C)=O)[C@H](OC(C)=O)C(OC(C)=O)[C@@H]1OC(C)=O</smiles><smiles>O=[W]OC(O)F</smiles><smiles>CC(=O)OC1C(C(=O)O)OC(C(=O)O)C(OC(C)=O)C1OC(C)=O</smiles> 


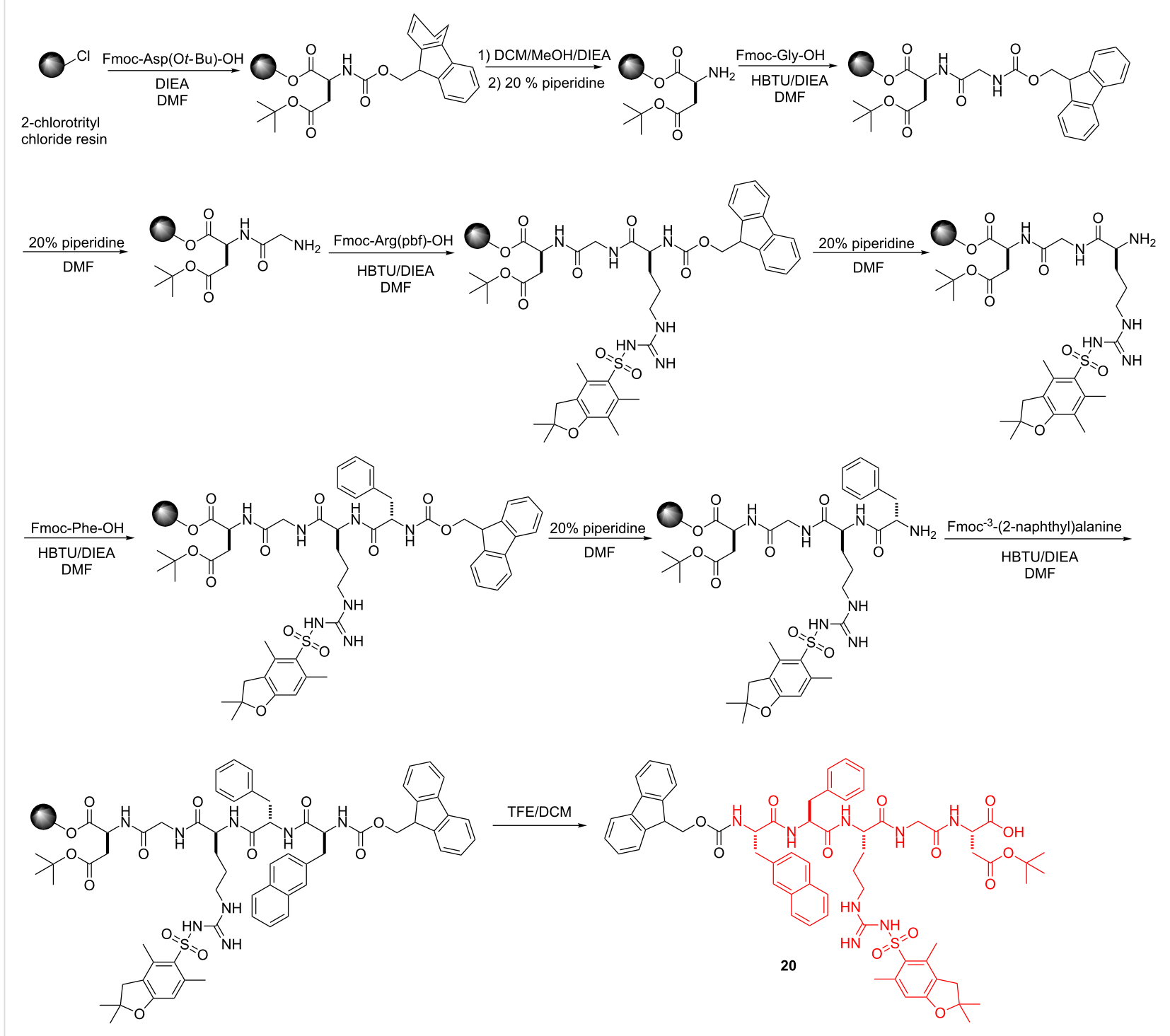

Scheme 2: Solid-phase peptide synthesis of peptide segment Fmoc-naphthAla-Phe-Arg(pbf)-Gly-Asn(Ot-Bu)-OH (20).

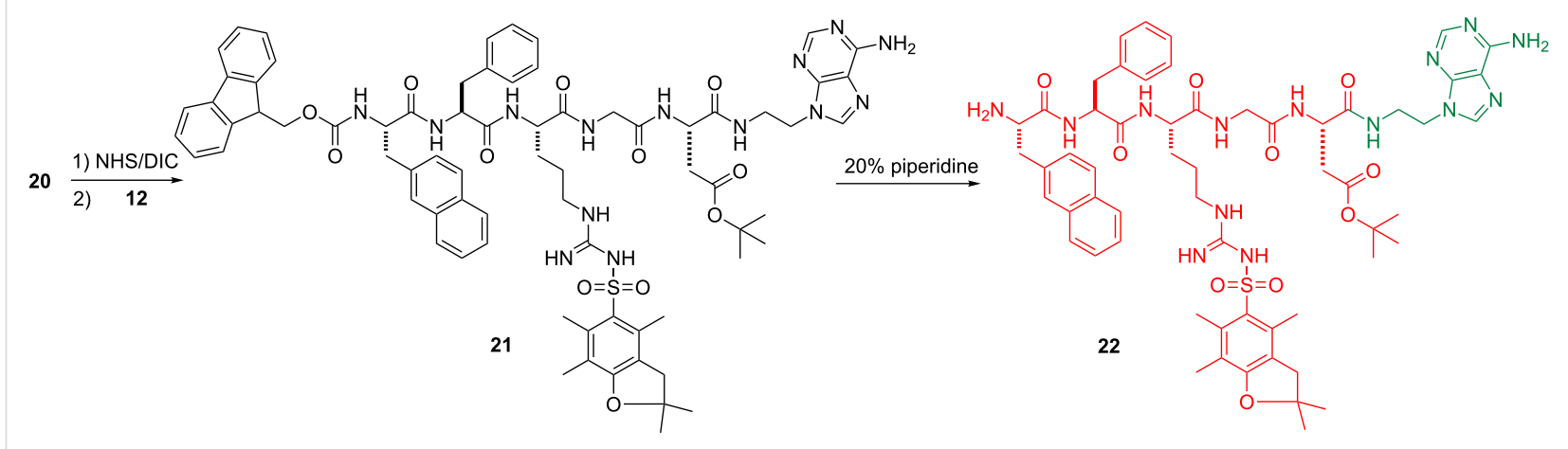

Scheme 3: Synthesis of H-naphthAla-Phe-Arg(pbf)-Gly-Asn(Ot-Bu)-adenine (22). 


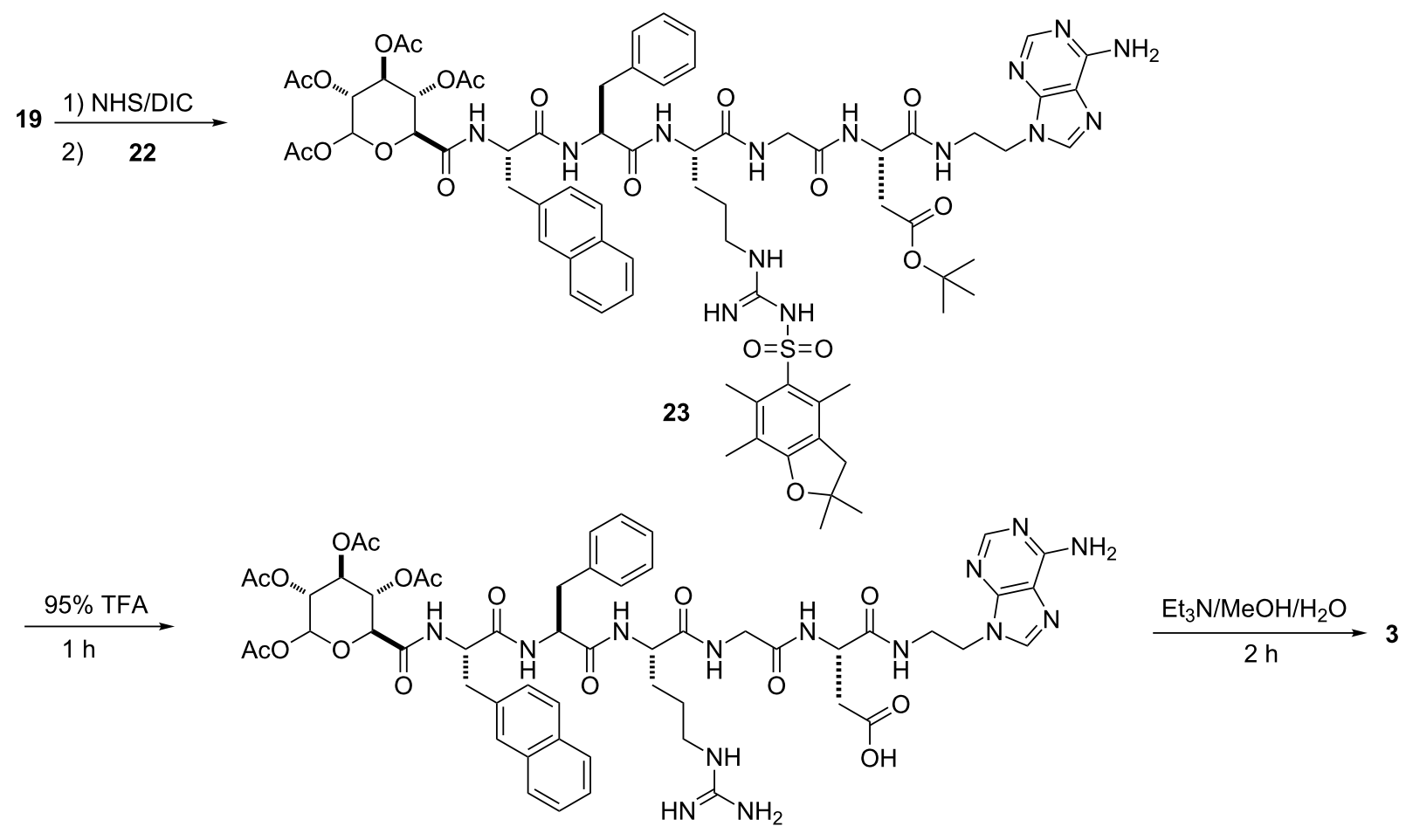

Scheme 4: Synthesis of saccharide-amino acids-nucleobase conjugate 3

S2B). The corresponding TEM images showed that conjugates 1-4 all form aggregates (upon drying) without ordered structures. Meanwhile, the removal of the saccharide from the SANtype conjugates, which forms compound $\mathbf{5 - 8}$, results in no hydrogel (Supporting Information File 1, Figure S1C, D and Figure S2C, D). These results suggest that the sequences of the three types of fundamental biological building blocks in the conjugates are critical for their self-assembly.

\section{Cell compatibility}

To investigate the cell compatibility of the conjugates, we incubated compounds 1-8 with HeLa cells [37] for 3 days at a concentration range from $20 \mu \mathrm{M}$ to $500 \mu \mathrm{M}$. We compared the cytotoxicity of conjugates 1, 2, 5, and $\mathbf{6}$ in Figure 2. Compounds $\mathbf{5}$ and $\mathbf{6}$ serve as the control for compounds $\mathbf{1}$ and $\mathbf{2}$ since they do not have a saccharide part. The viability of HeLa cells incubated with 1, 2, 5, and $\mathbf{6}$ is around $100 \%$ at the study concentrations for 3 days. Also conjugates 3, 4, 7, and 8 exhibit little toxicity to HeLa cells (Figure 3). Particularly, the cytotoxicities of conjugates $\mathbf{1}, \mathbf{3}-\mathbf{5}$, and $\mathbf{8}$ are slightly higher than $100 \%$ at $72 \mathrm{~h}$, it is likely originate from the metabolic activity increase in the HeLa cells treated by $\mathbf{1}, \mathbf{3}-\mathbf{5}$, and $\mathbf{8}$ [38]. These results are consistent with our previous reports that NAS- and NSA-type conjugates are cell compatible, indicating that the sequences of the three types of building blocks have slight influences to their cell responses. Based on these results, we speculate that the cell compatibility of this type of conjugate is not only due to the natural building blocks, but also may originate from their inability to form aggregates at low concentrations.

\section{Conclusion}

In summary, this article reports the synthesis of novel conjugates containing three fundamental biological build blocks (saccharide, amino acids, and nucleobase) and their cell compatibility. The attachment of the saccharide to the $N$-terminal of the peptide or the nucleobase to the $C$-terminal of the peptide apparently reduces the self-assembly ability of these conjugates in water. Although the atomistic details remain to be elucidated, the observation itself is intriguing. These results provide a new understanding of the self-assembly of the conjugates consisting of fundamental building blocks of biomacromolecules. One potential application of these SAN-type conjugates is to minimize unwanted aggregates of drug candidates for increasing the efficacy of drugs, which is a direction worth exploring. 

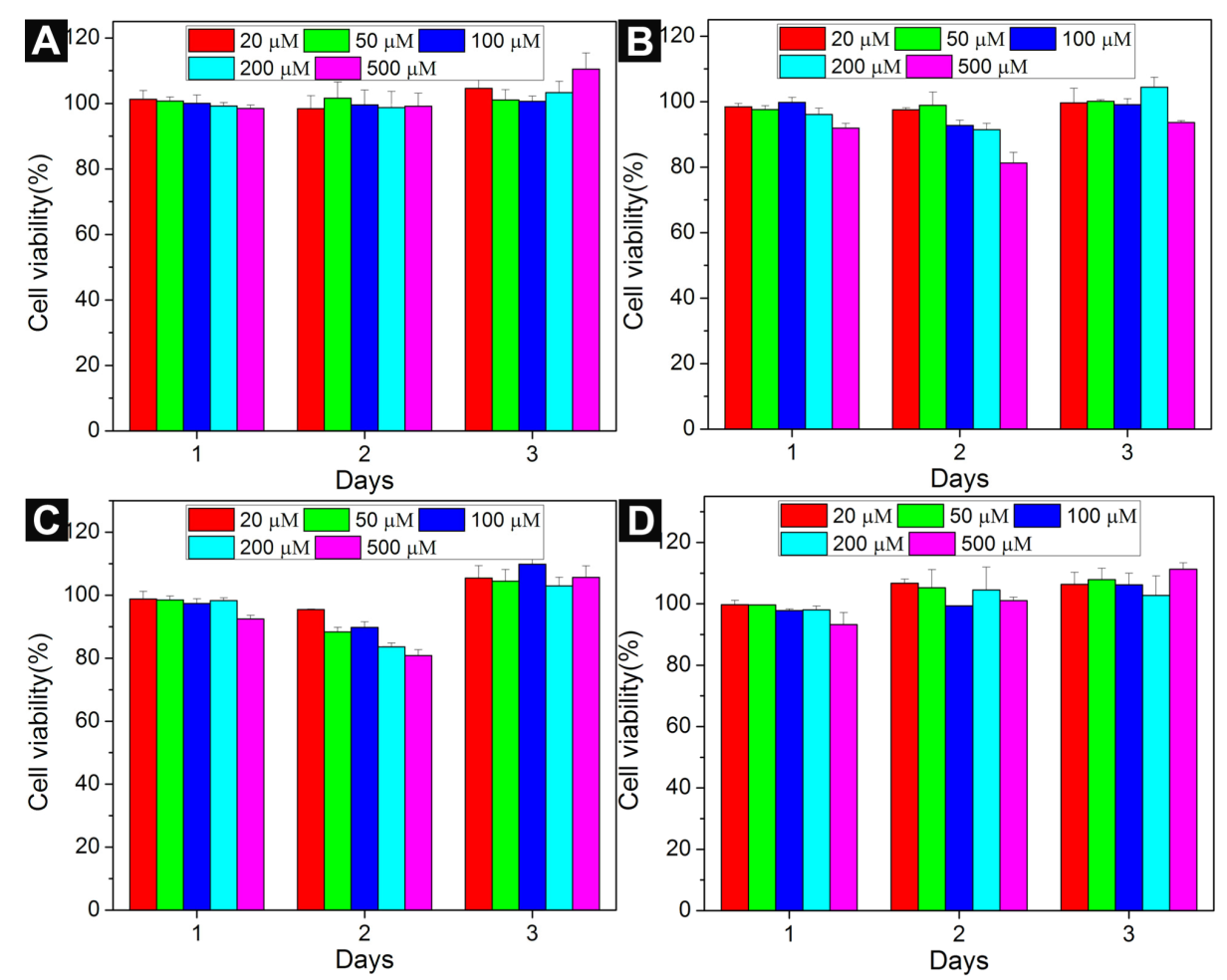

Figure 2: Cell viability of HeLa cells incubated with (A) 1, (B) 2, (c) 5, (D) 6 at different concentrations for 3 days.
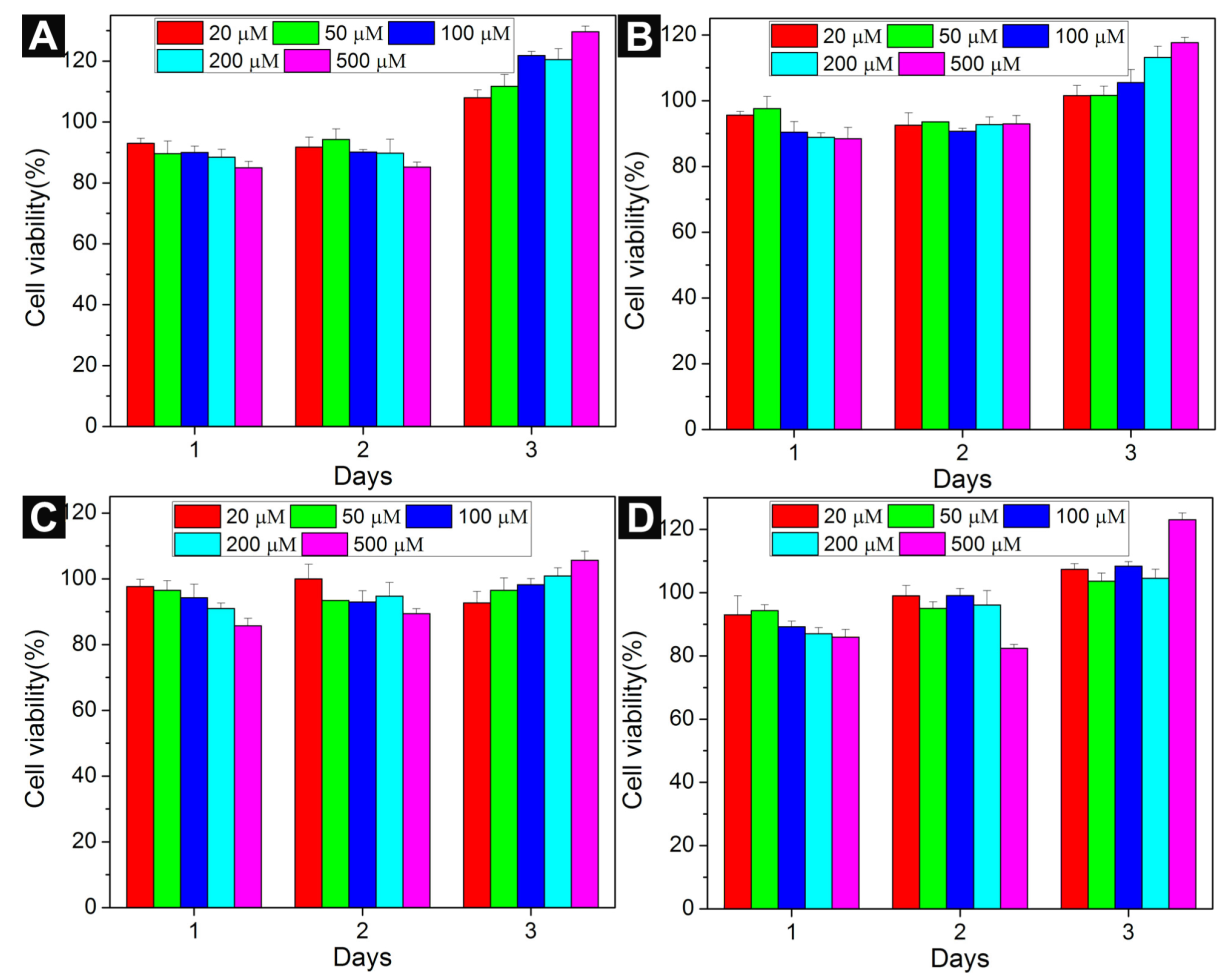

Figure 3: Cell viability of HeLa cells incubated with (A) 3, (B) 4, (C) 7, (D) 8 at different concentrations for 3 days. 


\section{Supporting Information}

\section{Supporting Information File 1}

General section, experimental section, TEM images of solutions of 1-8.

[http://www.beilstein-journals.org/bjoc/content/ supplementary/1860-5397-10-250-S1.pdf]

\section{Acknowledgments}

This work was partially supported by grant from NIH (R01CA142746) and a grant from KAU (44-130-35-HiCi). We thank the Brandeis EM facility at Brandeis University. D.Y. is grateful for a scholarship from the Chinese Scholarship Council (2010638002).

\section{References}

1. Izawa, H.; Kawakami, K.; Sumita, M.; Tateyama, Y.; Hill, J. P.; Ariga, K. J. Mater. Chem. B 2013, 1, 2155-2161. doi:10.1039/c3tb00503h

2. Ellis-Behnke, R. G.; Liang, Y.-X.; You, S.-W.; Tay, D. K. C.; Zhang, S.; So, K.-F.; Schneider, G. E. Proc. Natl. Acad. Sci. U. S. A. 2006, 103, 5054-5059. doi:10.1073/pnas.0600559103

3. Horii, A.; Wang, X.; Gelain, F.; Zhang, S. PLoS One 2007, 2, e190. doi:10.1371/journal.pone.0000190

4. Tian, Y.; Wang, H.; Liu, Y.; Mao, L.; Chen, W.; Zhu, Z.; Liu, W.; Zheng, W.; Zhao, Y.; Kong, D.; Yang, Z.; Zhang, W.; Shao, Y.; Jiang, X. Nano Lett. 2014, 14, 1439-1445. doi:10.1021/nl404560v

5. He, M.; Li, J.; Tan, S.; Wang, R.; Zhang, Y. J. Am. Chem. Soc. 2013, 135, 18718-18721. doi:10.1021/ja409000b

6. Qin, L.; Duan, P.; Xie, F.; Zhang, L.; Liu, M. Chem. Commun. 2013, 49, 10823-10825. doi:10.1039/c3cc47004k

7. Ochi, R.; Kurotani, K.; Ikeda, M.; Kiyonaka, S.; Hamachi, I. Chem. Commun. 2013, 49, 2115-2117. doi:10.1039/c2cc37908b

8. Yamamichi, S.; Jinno, Y.; Haraya, N.; Oyoshi, T.; Tomitori, H.; Kashiwagi, K.; Yamanaka, M. Chem. Commun. 2011, 47, 10344-10346. doi:10.1039/c1cc13826j

9. Kiyonaka, S.; Sada, K.; Yoshimura, I.; Shinkai, S.; Kato, N.; Hamachi, I. Nat. Mater. 2004, 3, 58-64. doi:10.1038/nmat1034

10. Tamesue, S.; Takashima, Y.; Yamaguchi, H.; Shinkai, S.; Harada, A. Angew. Chem., Int. Ed. 2010, 49, 7461-7464. doi:10.1002/anie.201003567

11. Araki, K.; Yoshikawa, I. Nucleobase-containing gelators. Low Molecular Mass Gelator; Topics in Current Chemistry, Vol. 256; Springer: Berlin, Heidelberg, 2005; pp 133-165. doi:10.1007/b107173

12. Babu, S. S.; Praveen, V. K.; Ajayaghosh, A. Chem. Rev. 2014, 114, 1973-2129. doi:10.1021/cr400195e

13. Shome, A.; Debnath, S.; Das, P. K. Langmuir 2008, 24, 4280-4288. doi:10.1021/la704024p

14. Zhou, M.; Smith, A. M.; Das, A. K.; Hodson, N. W.; Collins, R. F.; Ulijn, R. V.; Gough, J. E. Biomaterials 2009, 30, 2523-2530. doi:10.1016/j.biomaterials.2009.01.010

15. Tan, H.; Xiao, C.; Sun, J.; Xiong, D.; Hu, X. Chem. Commun. 2012, 48, 10289-10291. doi:10.1039/c2cc35449g

16. Li, X.; Kuang, Y.; Shi, J.; Gao, Y.; Lin, H.-C.; Xu, B. J. Am. Chem. Soc. 2011, 133, 17513-17518. doi:10.1021/ja208456k

17. Li, X.; Du, X.; Gao, Y.; Shi, J.; Kuang, Y.; Xu, B. Soft Matter 2012, 8, 7402-7407. doi:10.1039/c2sm25725d
18. Li, X.; Kuang, Y.; Xu, B. Soft Matter 2012, 8, 2801-2806. doi:10.1039/c2sm06920b

19. Wu, D.; Zhou, J.; Shi, J.; Du, X.; Xu, B. Chem. Commun. 2014, 50, 1992-1994. doi:10.1039/c3cc48946a

20. Du, X.; Zhou, J.; Guvench, O.; Sangiorgi, F. O.; Li, X.; Zhou, N.; Xu, B. Bioconjugate Chem. 2014, 25, 1031-1035. doi:10.1021/bc500187m

21. Zhang, Y.; Kuang, Y.; Gao, Y.; Xu, B. Langmuir 2011, 27, 529-537. doi:10.1021/la1020324

22. Chen, L.; Morris, K.; Laybourn, A.; Elias, D.; Hicks, M. R.; Rodger, A.; Serpell, L.; Adams, D. J. Langmuir 2010, 26, 5232-5242. doi:10.1021/la903694a

23. Smith, A. M.; Williams, R. J.; Tang, C.; Coppo, P.; Collins, R. F.; Turner, M. L.; Saiani, A.; Ulijn, R. V. Adv. Mater. 2008, 20, 37-41. doi:10.1002/adma.200701221

24. Fleming, S.; Debnath, S.; Frederix, P. W. J. M.; Tuttle, T.; Ulijn, R. V. Chem. Commun. 2013, 49, 10587-10589. doi:10.1039/c3cc45822a

25. Palmer, L. C.; Stupp, S. I. Acc. Chem. Res. 2008, 41, 1674-1684. doi:10.1021/ar8000926

26. Venkateswara Rao, B.; Dhokale, S.; Rajamohanan, P. R.; Hotha, S. Chem. Commun. 2013, 49, 10808-10810. doi:10.1039/c3cc46634e

27. Shi, J.; Gao, Y.; Yang, Z.; Xu, B. Beilstein J. Org. Chem. 2011, 7, 167-172. doi:10.3762/bjoc.7.23

28. Ruoslahti, E. Annu. Rev. Cell Dev. Biol. 1996, 12, 697-715. doi:10.1146/annurev.cellbio.12.1.697

29. Ojima, I.; Chakravarty, S.; Dong, Q. Bioorg. Med. Chem. 1995, 3 , 337-360. doi:10.1016/0968-0896(95)00036-G

30. Li, X.; Kuang, Y.; Lin, H.-C.; Gao, Y.; Shi, J.; Xu, B. Angew. Chem., Int. Ed. 2011, 50, 9365-9369. doi:10.1002/anie.201103641

31. Pandey, M. D.; Mishra, A. K.; Chandrasekhar, V.; Verma, S. Inorg. Chem. 2010, 49, 2020-2022. doi:10.1021/ic9022008

32. Elidrisi, I.; Negin, S.; Bhatt, P. V.; Govender, T.; Kruger, H. G.; Gokel, G. W.; Maguire, G. E. M. Org. Biomol. Chem. 2011, 9 , 4498-4506. doi:10.1039/c0ob01236j

33. Das, B. K.; Shibata, N.; Takeuchi, Y. J. Chem. Soc., Perkin Trans. 1 2002, 197-206. doi:10.1039/B108760F

34. Tosin, M.; Murphy, P. V. Org. Lett. 2002, 4, 3675-3678. doi:10.1021/ol026629j

35. Cagnoni, A. J.; Varela, O.; Gouin, S. G.; Kovensky, J.; Uhrig, M. L. J. Org. Chem. 2011, 76, 3064-3077. doi:10.1021/jo102421e

36. Chan, W. C.; White, P. D. Basic Procedures. In Fmoc Solid Phase Peptide Synthesis: A Practical Approach; Chan, W. C.; White, P. D., Eds.; Oxford University Press Inc.: New York, 2000; pp 41-73.

37. Masters, J. R. Nat. Rev. Cancer 2002, 2, 315-319. doi:10.1038/nrc775 38. Wang, P.; Henning, S. M.; Heber, D. PLoS One 2010, 5, e10202. doi:10.1371/journal.pone.0010202 


\section{License and Terms}

This is an Open Access article under the terms of the Creative Commons Attribution License

(http://creativecommons.org/licenses/by/2.0), which permits unrestricted use, distribution, and reproduction in any medium, provided the original work is properly cited.

The license is subject to the Beilstein Journal of Organic Chemistry terms and conditions:

(http://www.beilstein-journals.org/bjoc)

The definitive version of this article is the electronic one which can be found at:

doi:10.3762/bjoc. 10.250 